\title{
FESTIVALS IN GENESIS 1:14
}

\author{
David J. Rudolph
}

\begin{abstract}
Summary
The study presents a case for translating מוֹעַד in Genesis 1:14 as 'festivals' or 'festivals and seasons'. After surveying the growing support for this rendering in biblical scholarship, the article considers the evidence of usage, literary context, ANE background, and Second Temple Jewish literature.
\end{abstract}

\section{Introduction}

The goal of this essay is to demonstrate that a reasonable case can be made for translating מוֹשֶׁרים in Genesis 1:14 as 'festivals' or 'festivals and seasons'. ${ }^{1}$ Support for the rendering is found in modern English translations (e.g. GNB, NJB, NEB, REB). ${ }^{2}$ In addition, an increasing number of non-English translations have adopted the 'festivals'

\footnotetext{
1 It is beyond the scope of this study to evaluate the natural (independent of cultic festivals) or ambiguous 'seasons' rendering (KJV, NKJV, NIV, NRSV, RSV, ASV, NASB, ESV, CEV, NCV, The Message, Jacobus, Delitzsch, Conant, Cassuto, Ramban, Ibn Janach), the ambiguous or hendiadys 'fixed times' rendering (NAB, JPS, NJPS, Speiser, Smith and Goodspeed, Schocken, Sauer, Clines, Fuerst) or the 'hours' rendering (Ibn Ezra). For a full treatment of these alternative translations, see David J. Rudolph, 'Israel's Festivals in the Fourth Day of Creation: The Meaning of מוֹעִדים in Genesis 1:14' (M.A. thesis, Gordon-Conwell Theological Seminary, 2002).

2 The 'festivals' rendering is maintained by: The Good News Bible, The New Jerusalem Bible, The Jerusalem Bible, The Artscroll Tanach (Stone), The Living Torah (Kaplan), Bereishis (Zlotowitz), and Genesis Elucidated (Jervis). In addition, several versions have adopted comparable translation values: Moffatt and The Emphasized Bible ('sacred seasons'), The Pentateuch by Hirsch ('festival times') and the Margolin Edition Torah ('periodic festive occasions'). The New English Bible and the Revised English Bible put forward a more expanded version ('festivals and seasons').
} 
'festivals and seasons' rendering, following recommendations in the 1997 United Bible Society Translation Handbook. ${ }^{3}$

Standard lexicons and theological dictionaries support the 'festivals' rendering, including Koehler-Baumgartner, Holladay, BDB, TWOT, and TDOT. ${ }^{4}$ Koch notes:

The fixed seasons in the course of the year are at the same time the fixed times of festivals. Though the moon plays an especially decisive role, the sun is also of consequence: 'He made the moon for the מועערדים; the sun knows its (time for) rising' (Ps. 104:19). A similar sense is expressed by the famous passage Gen. $1: 14$, according to which the celestial bodies were created to be 'for signs and for (regular) times of festivals and for days and years' (cf. Sir. 43:7). 1QS 9:26-10:8 extensively discusses the relationship between the natural and cultic year from the perspective of מועד

Over the past 130 years, a number of commentators have favoured 'festivals' as the most accurate translation of מוֹעִ דידים in Genesis 1:14. In line with this trend, John Skinner wrote in his 1910 International Critical Commentary on Genesis:

(מוֹעִדים (seasons) appears never (certainly not in P) to be used of the natural seasons of the year (Ho. 2.11, Jer. 8.7 are figurative), but always of a time conventionally agreed upon (see Ex. 9.5), or fixed by some circumstance. The commonest application is to the sacred seasons of the ecclesiastical year, which are fixed by the moon (cf. Ps. 104.19). If the natural seasons are excluded, this seems the only possible sense here; and P's predilection for matters of cultus makes the explanation plausible. ${ }^{7}$

3 William D. Reyburn and Euan McG. Fry, A Handbook of Genesis (UBS Handbook Series 1; New York: United Bible Societies, 1997), 42.

4 Ludwig Koehler \& Walter Baumgartner, The Hebrew and Aramaic Lexicon of the Old Testament II (tr. M.E.J. Richardson; New York: E.J. Brill, 1995), 558; William L. Holladay, A Concise Hebrew and Aramaic Lexicon of the Old Testament (Grand Rapids: Eerdmans, 1971), 186; Francis Brown, S.R. Driver \& Charles A. Briggs, A Hebrew and English Lexicon of the Old Testament (Oxford: Clarendon, 1907), 417; Jack P. Lewis, 'mô'èd' in Theological Wordbook of the Old Testament I (ed. R. Laird Harris, et al.; Chicago: Moody, 1980), 388-89; K. Koch, 'מוער' in Theological Dictionary of the Old Testament VIII (ed. G. Johannes Botterweck, et al.; Grand Rapids: Eerdmans, 1997), 167-73.

5 Koch, 'מועד', 170.

6 For earlier commentators, see Martin Luther, Luther's Commentary on Genesis I (tr. J. Theodore Mueller; Grand Rapids: Zondervan, 1958), 23; William Paul, Analysis and Critical Interpretation of the Hebrew Text of the Book of Genesis (Edinburgh: William Blackwood \& Sons, 1852), 16.

7 John Skinner, A Critical and Exegetical Commentary on Genesis (ICC; New York: Charles Scriber's Sons, 1910), 26. 
Lang, Davidson, Gowan, Scullion, Brodie, Towner, and Walton maintain this position. ${ }^{8}$ Among Rabbinic commentators, Rashi supports the 'festivals' translation. The expanded 'festivals and seasons' rendering, which emphasizes the central role of harvest festivals in Israel's calendar (a direct link to the natural 'seasons'), is supported by Wenham, Kidner, Hartley, Driver, Westermann, Bush, Alford, Spurrell, Leupold, and Fretheim. ${ }^{9}$

Several recent studies on Israel's calendar also uphold the 'festivals' translation. James VanderKam raises the issue of מוֹעִדים in Genesis 1:14 on page one of his book Calendars in the Dead Sea Scrolls, noting:

The term translated 'seasons' ( $m w^{\prime}$ 'dym) is one that elsewhere in the Bible means 'festivals'. Therefore, one could say that in this paragraph the sun and moon are given calendrical assignments for three of the entities that are significant in Biblical and post-Biblical calendars - days, years and festivals. ${ }^{10}$

Roger Beckwith addresses Genesis 1:14 in Calendar and Chronology, Jewish and Christian:

8 John Peter Lang, Genesis, or, the First Book of Moses (tr. Tayler Lewis \& A. Gosman; New York: Scharles Scribner \& Co., 1868), 171; Robert Davidson, Genesis 1-11 (Cambridge Bible Commentary; Cambridge: CUP, 1973), 21; Donald E. Gowan, From Eden to Babel: A Commentary on the Book of Genesis 1-11 (ITC; Grand Rapids: Eerdmans, 1988), 25; John J. Scullion, Genesis: A Commentary for Students, Teachers, and Preachers (Collegeville: Liturgical, 1992), 19; Thomas L. Brodie, Genesis as Dialogue: A Literary, Historical \& Theological Commentary (Oxford: OUP, 2001), 135; W. Sibley Towner, Genesis (Louisville: Westminster John Knox, 2001), 23; John H. Walton, Genesis (NIV Application Commentary 1; Grand Rapids: Zondervan, 2001), 122-23.

9 Gordon J. Wenham, Genesis 1-15 (WBC; Waco: Word, 1987). After listing three possible interpretations, Wenham, 23, concludes: 'What is clear is the importance attached to the heavenly bodies' role in determining the seasons, in particular in fixing the days of cultic celebration. This is their chief function'; cf. Derek Kidner, Genesis: An Introduction and Commentary (Chicago: Inter-Varsity, 1967), 49; John E. Hartley, Genesis (NIBC; Peabody: Hendrickson, 2000), 46; S.R. Driver, The Book of Genesis (London: Methuen \& Co., 1920), 10; Claus Westermann, Genesis 1-11 (Continental Commentary; tr. J.J. Scullion; Minneapolis: Fortress, 1994), 129-30; George Bush, Notes, Critical and Practical on the Book of Genesis I (Boston: Henry A. Young, 1870), 36; Henry Alford, The Book of Genesis (Minneapolis: Klock \& Kock, 1872), 6; G.J. Spurrell, Notes on the Text of the Book of Genesis (Oxford: Clarendon, 1896), 11; H.C. Leupold, Exposition of Genesis I (Grand Rapids: Baker, 1953), 74; Terence E. Fretheim, 'Genesis', in The New Interpreter's Bible I (ed. L.E. Keck; Nashville: Abingdon, 1994), 344.

10 James C. VanderKam, Calendars in the Dead Sea Scrolls: Measuring Time (New York: Routledge, 1998), 4. 
...when the lunar calendar appears in the Old Testament, it is often precisely in priestly, or cultic, contexts that it does so. Thus, it is hard to believe that Gen. 1:14-16 and Ps. 104:19 are referring simply to secular 'seasons'. ${ }^{11}$

Finally, Walter Vogels' SBL paper on 'The Cultic and Civil Calendars of the Fourth Day of Creation (Gen 1,14b)', the most comprehensive study of מוֹעֵ רים in Genesis 1:14 to date, ${ }^{12}$ assesses the translation background and placement of מוֹעִ משרים in the literary context of the creation account. Vogels concludes that 'festivals' is the most accurate translation of מוֹעִ עירים in Genesis 1.

\section{Survey of Usage Distribution}

There are 160 instances of the use of מוֹעֵ in the Torah. The usage distribution is as follows:

\section{a) Tent of Meeting}

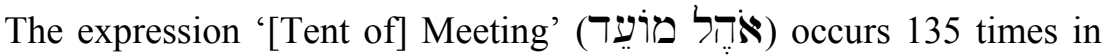
the Torah, eighty-four percent of all instances of מוֹערד. It is unlikely that מוֹעִַ in Genesis 1:14 refers directly to the Tent of Meeting for

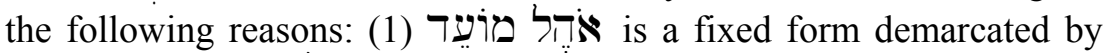
the construct noun אה אהל. The absence of the construct noun in Genesis 1:14 suggests that the Tent of Meeting is not at issue; (2) The reference

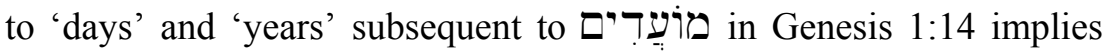
that appointed time is the emphasis rather than appointed place; (3) The

11 Roger T. Beckwith, Calendar and Chronology, Jewish and Christian: Biblical, Intertestamental and Patristic Studies (Leiden: E.J. Brill, 1996), 102. Other works that address מוֹעַדים in Genesis 1:14 include: Paul Beauchamp, Création et séparation: Étude exégétique du chapitre premier de la Genèse (Bibliothèque de Sciences religieuses; Aubier Montaigne, 1969), 114; Roland de Vaux, Ancient Israel: Its Life and Institutions (tr. John McHugh; Grand Rapids: Eerdmans, 1997), 178 ('We read in Gn 1:14 that God created the sun and moon "to divide the day from the night and to serve as signs, for feasts and for the days and the years"'); Norman H. Snaith, 'Time in the Old Testament', in Promise and Fulfillment: Essays Presented to Professor S.H. Hooke (ed. F.F. Bruce; Edinburgh: T\&T Clark, 1963), 178; and Solomon Gandz, 'The Calendar of Ancient Israel', in Homenaje a Millás-Valligrosa (Barcelona: Consejo Superior de Investigaciones Científicas, 1954), I:645. All of these works uphold a 'festivals' rendering.

12 Vogels' paper was published as 'The Cultic and Civil Calendars of the Fourth Day of Creation (Gen 1,14b)', Scandinavian Journal of the Old Testament 2 (1997) 163-80. 
plural noun מוֹעִדים in Genesis 1:14 is incongruous with the

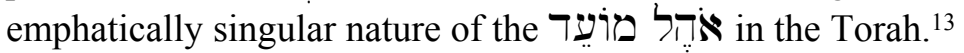

\title{
b) Assembly/Set Time for an Act of God
}

מוֹעיד refers to an 'assembly [of Israel]' once in the Torah (Nu. 16:2) and to a 'set time for an act of God' (Gn. 17:21; 18:14; 21:2; Ex. 9:5) four times. In all five of these passages, מוֹעֵ has no direct linkage to the sun, moon or stars (three vital context elements in Gn. 1:14), thus suggesting incompatibility. In Genesis 1:14, מוֹעַדים are a main purpose of the heavenly lights.

\section{c) Time of Offerings, Primarily for Festivals}

מוֹעיד occurs once in the Torah in the context of an inclusio that emphasizes festival offerings ( $\mathrm{Nu}$. 28:2).

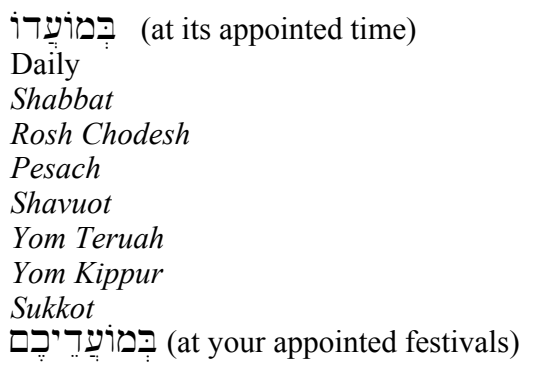

\author{
Numbers 28:2 \\ Numbers 28:3-8 \\ Numbers 28:9-10 \\ Numbers 28:11-15 \\ Numbers 28:16-25 \\ Numbers 28:26-31 \\ Numbers 29:1-6 \\ Numbers 29:7-11 \\ Numbers 29:12-38 \\ Numbers 29:39
}

The Numbers 28:2 use of מוֹעיד is compatible with the meaning of in Genesis 1:14 since 'festival offerings' are directly regulated by the sun, moon and stars, and could not exist without these luminaries. This having been said, 'festivals'/'festivals and seasons' may be a preferred translation because festival offerings (some of which are dependent on the agricultural cycle and the natural seasons) are a sub-category of festival observances, a point reinforced by the use

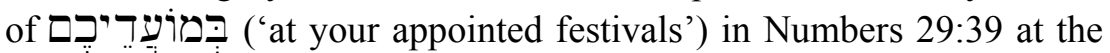
end of the inclusio.

\footnotetext{
13 See Menahem Haran, Temples and Temple-Service in Ancient Israel: An Inquiry into Biblical Cult Phenomena and the Historical Setting of the Priestly School (Winona Lake: Eisenbrauns, 1985), ch. xiv: 'The Non-Priestly Image of the Tent of $m o \hat{o} ' \bar{e} \underline{d}$ '. A late text that hints at linkage is 4Q320, which identifies the starting point of the mishmarot (priestly courses) of 1 Chronicles 24:7-18 with the fourth day of creation (VanderKam, Calendars, 79).
} 


\section{d) Time of Commemorating Pesach}

מוֹעיד refers to the 'time of commemorating Pesach' once in the Torah (Dt. 16:6). Pesach occurs on a full moon at the beginning of Israel's calendar year. The sun and stars also regulate the timing of Pesach, which coincides with a harvest festival in the first month (Lv. 23:9-14) and begins at a particular time of day, twilight. Given this dependence on sun, moon and stars, Pesach would seem to be compatible with the

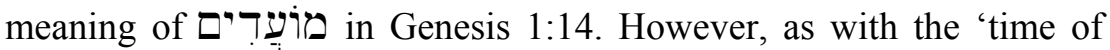
festival offerings', the 'time of commemorating Pesach' is probably too narrow an interpretation of מוֹעִדים to fit the Genesis 1 context since Pesach is the first festival of an annual cycle of festivals. The more inclusive term 'festivals'/'festivals and seasons' is therefore to be preferred in Genesis 1:14.

\section{e) Appointed Time of a Festival}

מוֹעיד entails the meaning 'appointed time of a festival' nine times in the Torah; ${ }^{14}$ references are to the full festival cycle, Pesach, Matzot and Sukkot (Ex. 13:10; 23:15; 34:18; Lv. 23:4; Nu. 9:2, 3, 7, 13; Dt. 31:10). Notably, all three of the latter festivals are dramatically linked to the heavenly lights since they fall on full moons. This broad and graphic identification of מוֹעיד with Israel's festival cycle, an institution established by divine decree and regulated by heavenly lights, serves to buttress the case that מוֹעִדים in Genesis 1:14 refers to Israel's festivals. The next section will attempt to advance this argument further.

\section{f) Festivals}

מוֹעיד explicitly means festivals eight times in the Torah (Lv. 23:2 [2×], 4, 37, 44; Nu. 10:10; 15:3; 29:39). All eight of these references are to the full cycle of Israel's festivals. Moreover, all of these occurrences of מוֹעַדים are plural nouns like מוֹער in Genesis 1:14. Of the 160 occurrences of מוֹער in the Torah, only nine are plural. Of

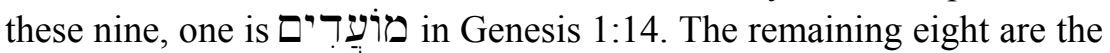
ones listed above, all of which unambiguously mean 'festivals'.

The identification of מוֹעִדים with 'festivals' is especially highlighted in Leviticus 23. Here the construct plurals מוֹעִ מִדרי

14 This section was set off from the previous one ('Time of Commemorating Pesach') because Deuteronomy 16:6 seems to emphasize the 'time' of day when Israel departed from Egypt. 
מוֹעֵדרי appear to form an inclusio not unlike the one in Numbers 2829. The content of this inclusio, however, goes beyond the narrow focus on festival 'offerings' in Numbers 28-29 and covers a range of festival-related observances (e.g. sacrifices, assemblies, rest days, eating matzah, fasting, blowing the ram's horn, rejoicing with choice fruit from the harvest and leafy branches, dwelling in booths, etc.). In Leviticus 23, מוֹעַד (in construct form) is identified with 'festivals' in its broadest and most comprehensive sense:

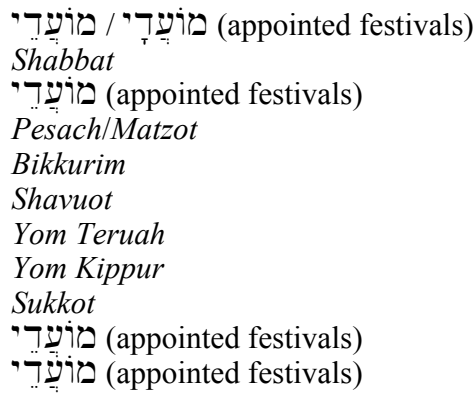

Leviticus 23:2
Leviticus 23:3
Leviticus 23:4
Leviticus 23:4-8
Leviticus 23:9-14
Leviticus 23:15-22
Leviticus 23:23-25
Leviticus 23:26-32
Leviticus 23:33-43
Leviticus 23:37
Leviticus 23:44

In sum, there are 160 occurrences of מוֹעיד in the Torah that can be divided into six categories of meaning. The first two categories of meaning are not compatible with the Genesis 1:14 context and can be precluded on this basis. The remaining four categories all refer directly to aspects of Israel's festival cycle or to the cycle as a whole. The following four tables compare the above findings with data from the rest of the Hebrew Bible.

\section{Table 1: Usage Distribution of מוֹעِ in the Hebrew Bible}

מוֹעיד in the Torah

135 [Tent of] Meeting

19 Festival-Related

- Time of Offerings, esp. Festivals (1) 4

- $\quad$ Time Commemorating Pesach (1) 1

- $\quad$ Appointed Time of a Festival (9)

- $\quad$ Festivals (8)

5 Assembly/Set Time for Act of God

1 מוֹשְרִים 1 in Gn. 1:14 [?]

$160 \quad$ - Total in the Historical Books

11 [Tent of] Meeting

6 Festivals

4 Set Time Appointed by Prophet

Meeting Place

1 Appointed Signal

1 Appointed Food

1 Appointed Cities

1 Providential Time

1 Appointment between Friends

1 Set Time Appointed by King

28 - Total 


\begin{tabular}{|c|c|c|c|}
\hline & מוֹעِד in the Poetical Books & & מוֹעֵ in the Prophetical Books \\
\hline 5 & Festivals & 12 & Festivals \\
\hline 3 & Meeting Places & 5 & End of Time \\
\hline 2 & Time of Judgment & 2 & Measurement of Time \\
\hline 1 & Appointed Time in God's Plan & 1 & Mount of Assembly \\
\hline \multirow[t]{4}{*}{1} & Appointed Place in Death & 1 & Ranks of an Army \\
\hline & & 1 & Stork's Migratory/Nest Seasons \\
\hline & & 1 & Time of Opportunity \\
\hline & & 1 & Time of Readiness \\
\hline 12 & - Total: & 24 & - Total \\
\hline
\end{tabular}

\section{Table 2: How Often the Plural of מוֹעِ Means 'Festivals'}

$\begin{array}{lll}\text { Bible Genre } & \text { Ratio } & \text { Percentage } \\ \text { Torah } & 8 / 8 & 100 \% \\ \text { Historical Books } & 6 / 6 & 100 \% \\ \text { Poetical Books } & 1 / 2 & 50 \% \\ \text { Prophetical Books } & 7 / 10 & 70 \%\end{array}$

A complete picture of how the plural of מוֹעיד is used in the Hebrew Bible is tallied below according to genre:

\section{Table 3: Summary of All Plural Forms of מוֹעִ in the Hebrew Bible}

\begin{tabular}{|c|c|c|c|}
\hline Citation & Form & Parsing & Meaning \\
\hline $\begin{array}{l}\text { Torah } \\
\text { Gn. } 1: 14 \\
\text { Lv. } 23: 2 \\
\text { Lv. } 23: 2 \\
\text { Lv. } 23: 4 \\
\text { Lv. 23:37 } \\
\text { Lv. 23:44 } \\
\text { Nu. 10:10 } \\
\text { Nu. 15:3 } \\
\text { Nu. 29:39 }\end{array}$ & 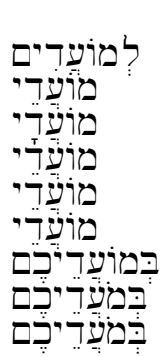 & 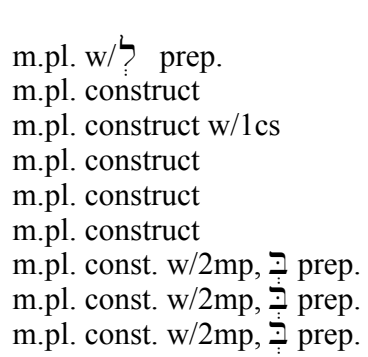 & $\begin{array}{l}\quad[?] \\
\text { Festivals } \\
\text { Festivals } \\
\text { Festivals } \\
\text { Festivals } \\
\text { Festivals } \\
\text { Festivals } \\
\text { Festivals } \\
\text { Festivals }\end{array}$ \\
\hline $\begin{array}{l}\text { Historical Book } \\
1 \text { Ch. } 23: 31 \\
2 \text { Ch. } 2: 4[3] \\
2 \text { Ch. } 8: 13 \\
2 \text { Ch. } 31: 3 \\
\text { Ezr. 3:5 } \\
\text { Ne. 10:33[4] } \\
\text { Poetical }\end{array}$ & 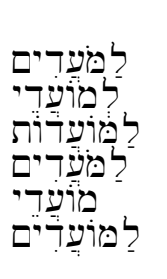 & $\begin{array}{l}\text { m.pl. w/? prep. } \\
\text { m.pl. const. w/? prep. } \\
\text { m.pl.w/ל prep. } \\
\text { m.pl.w } / \text { ? prep. } \\
\text { m.pl. construct } \\
\text { m.pl.w/? prep. }\end{array}$ & $\begin{array}{l}\text { Festivals } \\
\text { Festivals } \\
\text { Festivals } \\
\text { Festivals } \\
\text { Festivals } \\
\text { Festivals }\end{array}$ \\
\hline $\begin{array}{l}\text { Ps. } 74: 8 \\
\text { Ps. } 104: 19\end{array}$ & למוֹעַדַים & $\begin{array}{l}\text { m.pl. construct } \\
\text { m.pl.w/ל prep. }\end{array}$ & $\begin{array}{l}\text { Meeting places } \\
\text { Festivals } 15\end{array}$ \\
\hline
\end{tabular}

15 Psalm 104:19a ('He made/appointed the moon for מוֹעִד י...') cannot refer to the natural seasons since the natural seasons are regulated by the sun due to the earth's tilt, not the moon. By contrast, the moon is given pride of place in the Hebrew Bible as the primary luminary that regulates Israel's festival cycle (Nu. 10:10; 1 Sa. 20:5, 18, 24; 2 
Prophetical Books

\begin{tabular}{|c|c|c|c|}
\hline Is. $1: 14$ & 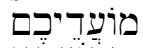 & m.pl. const. w/2mp & Festivals \\
\hline Is. $14: 31$ & בְּמוֹעָדָיו & m.pl. const. w/3ms, $\ni$ prep. & Ranks \\
\hline Je. $8: 7$ & 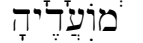 & m.pl. const. w/3fs & Stork's seasons \\
\hline Ezk. 36:38 & בَמְוֹעٍ & m.pl. const. w/3fs, $\supseteq$ prep. & Festivals \\
\hline Ezk. 44:24 & 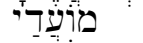 & m.pl. construct $\mathrm{w} / 1 \mathrm{cs}$ & Festivals \\
\hline Ezk. 45:17 & 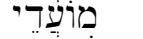 & m.pl. construct & Festivals \\
\hline Ezk. 46:9 & 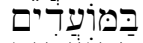 & m.pl. w/ב prep. & Festivals \\
\hline Ezk. 46:11 & 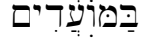 & m.pl. w/ב prep. & Festivals \\
\hline Dn. $12: 7$ & מִ מוֹעַדִים & m.pl. & Times \\
\hline Zc. 8:19 & 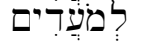 & m.pl.w/? prep. & Festivals \\
\hline
\end{tabular}

To sum up, out of 224 occurrences of מוֹעיד in the Hebrew Bible, 197 are singular and twenty-seven are plural (including Gn. 1:14). Table 3 indicates that of the twenty-six plural forms subsequent to the creation account, twenty-two mean 'festivals'. This demonstrates that the plural form of מוֹטיָד eighty-five percent of the time means 'festivals' in the Hebrew Bible. The figure rises to one hundred percent in the Torah, the literary background of Genesis 1:14. Moreover, when all of the exact lexical forms of מוֹעיד in Genesis 1:14 are extracted from Table 3 and evaluated, the 'festivals' rendering occurs one hundred percent of the time.

\section{Table 4: All Occurrences of לִ מוֹעַדים in the Hebrew Bible}

\begin{tabular}{|c|c|c|c|c|}
\hline Citation & Form & Parsing & & Meaning \\
\hline Gn. 1:14 & לִמוֹעַדים & m.pl. w/? & prep. & [?] \\
\hline 1 Ch. 23:31 & 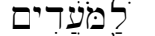 & m.pl. w/ & prep. & Festivals \\
\hline 2 Ch. $31: 3$ & 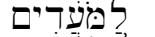 & m.pl. w/ ? & prep. & Festivals \\
\hline Ne. 10:33[4] & 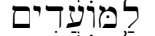 & m.pl.w/? & prep. & Festivals \\
\hline Ps. $104: 19$ & 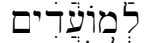 & m.pl. w/ ? & prep. & Festivals \\
\hline Zc. 8:19 & 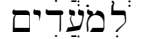 & m.pl. w/ & prep. & Festivals \\
\hline
\end{tabular}

\section{Literary Context}

We now turn to two elements of literary context in Genesis 1:1-2:3 that support a 'festivals' interpretation: priestly language and havdil imagery.

Ki. 4:23; 1 Ch. 23:31; Ezr. 3:5; Ne. 10:33[34]; Ps. 81:3-4[4-5]; Is. 1:14; 66:23; Ezk. 46:1, 6; Ho. 5:7; Am. 8:5). Consider that all festival dates point to the moon (e.g. Pesach $=$ fourteenth day of the first month $=$ full moon of the first lunar cycle). The sun affects this cycle by regulating the length of days and agricultural seasons, which must coincide with Israel's harvest festivals (Bikkurim, Shavuot, Sukkot). The secondary role of the sun vis-à-vis the festivals is suggested in Ps. 104:19b by its secondary mention, even though it is the larger luminary. 


\section{a) Priestly Language}

The festivals rendering is affirmed by liturgical language in the creation account, ${ }^{16}$ language that has led to Genesis 1 being designated a $\mathrm{P}$ source in redaction critical studies. ${ }^{17}$ The fourth day of creation, in particular, stresses the cultic aspect by using the term מָאוֹ (lamp) as a metonymy for sun and moon (Gn. 1:14, 15, $16[3 \times])$. All other

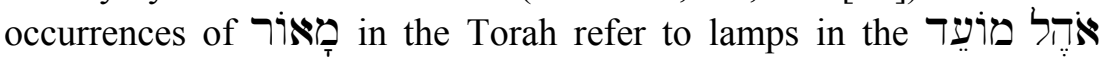
(Ex. 25:6; 27:20; 35:8, 14, 28; 39:37; Lv. 24:2; Nu. 4:9, 16). Among

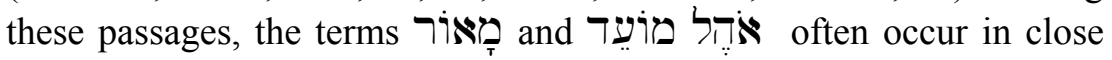
proximity (e.g. Ex. 27:20-21; 35:21-28; 39:37-40; Lv. 24:2-3; Nu. $4: 15-16$ ), further emphasizing the cultic relationship. It may be argued that the writer of Genesis 1 uses this cultic imagery to depict the sun and moon as being like 'sacred lamps in the sanctuary of the

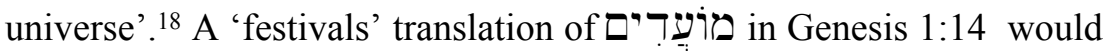
fit elegantly within this context since Israel's festivals were also cultic in nature. They were appointed times when offerings were presented to the Lord before the light of the מָז (Nu. 28:1-29:39).

16 W. Brueggemann, 'The Way of the Liturgy: A Detailed Study', in Genesis: A Bible Commentary for Teaching and Preaching (Atlanta: John Knox, 1982), 29-39.

17 Bruce K. Gardner, The Genesis Calendar: The Synchronistic Tradition in Genesis 1-11 (New York: University Press of America, 2001), 62-63; Otto Eissfeldt, The Old Testament: The History of the Formation of the Old Testament (tr. Peter R. Ackroyd; New York: Harper \& Row, 1965), 188; Hermann Gunkel, Genesis (tr. Mark E. Biddle; Macon: Mercer University Press, 1997), 102-131. Although I myself do not hold to the documentary hypothesis, the view is common enough to make several comments. Of the 160 occurrences of מוֹער in the Torah, 149 (93\%) occur between Exodus 25 and Numbers 31, a section understood to include most of the work of the so-called priestly writer (P) (Koch, 'מועד', 167). 133 of these 149 occurrences are in construct with איהל ([Tent of] Meeting). Two additional examples of מהת מוֹעֵ Deuteronomy 31:14, for a combined total of 135 occurrences. Vogels, 'Cultic and Civil Calendars', 166, notes that the 'usage of mo'ed shows that the word is rarely used in the Deuteronomistic Literature and in books with less interest in liturgy, such as the prophets and wisdom. In all of wisdom literature the word appears only once and carries no liturgical connotation ( $\mathrm{Jb} .30,23)$. The word is used frequently in the Torah $(160 \times$, of which 135 for the tent of meeting). Among the prophets, Ezekiel uses it most often $(5 \times)$. It appears several times in Lamentations $(6 \times)$, and in the literature of the Chronist (Ezr [1×]), Neh [1×], 1 and $2 \mathrm{Chr}[12 \times$, of which $7 \times$ for the tent of meeting]). Clearly, the word mo'ed is part of priestly and liturgical language.'

18 Vogels, 'Cultic and Civil Calendars', 175. 


\section{b) Havdil Imagery}

Genesis 1 places strong emphasis on order and separation. God divides his creation into distinct spheres. ${ }^{19}$ Light is separated from darkness, day from night, waters above from waters below, earth from seas, plants from trees, birds from fish, cattle from wild animals, and male from female. ${ }^{20}$ The verb בדל (to separate) occurs five times in Genesis 1 (vv. 4, 6, 7, 14, 18). Notably, two out of the five references are to the fourth day of creation; one reference is in Genesis 1:14.

Viewed against this backdrop of havdil imagery, the string of plural

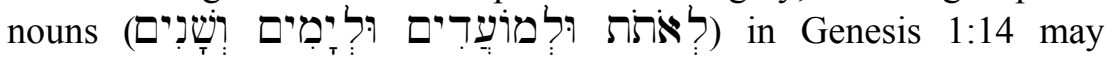
arguably be a division of two types of time: sacred time (signs ${ }^{21}$ and festivals) and ordinary time (days and years). ${ }^{22}$ Analogous to such a qualitative time distinction is the relationship between the first six days of creation and the seventh day. The seventh day was designated by

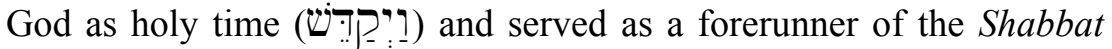
(Ex. 20:8-11), a festival central to Israel's cultic calendar. ${ }^{23}$

19 See Beauchamp, Création et séparation; E. Dantinne, 'Création et séparation', Le Muséon 74 (1961) 441-51; B. Ibal, 'Création, séparation et amour', Revue des sciences religieuses 66 (1992) 333-43.

20 Vogels, 'Cultic and Civil Calendars', 168.

21 'The Bible refers to such signs: the rainbow for Noah (Gen 9,12-13), or the stars for Abraham (Gen 15,5; Matt 2,2), or the sun (2 Kgs 20,8-10; Is 38,7; Mal 3,20), or all the heavenly lights in general (Joel 3,3; Matt 24,29; Rev 6,12-14). But at times the Bible also warns against those who study these heavenly signs (Jer 10,2; Is 47,13; Job 31,26)' (Vogels, 'Cultic and Civil Calendars', 167).

22 Vogels, 'Cultic and Civil Calendars', 169.

23 The relationship between the Shabbat and festivals is a close one in the Hebrew Bible, even to the extent that the Shabbat is designated as one of the מוֹעִ (Lv. 23:1-3). Vogels, 'Cultic and Civil Calendars', 178, argues on this basis, 'The sabbath belongs to the cultic calendar. The seventh day is one of these "festivals" mentioned in the fourth day'. Elsewhere in the Hebrew Bible, however, the Sabbath is noted side by side with the festivals and is considered distinct ( 1 Ch. 23:31; 2 Ch. 8:13; 31:3; Ne. 10:33 [34]; La. 2:6; Is. 1:13-14; Ho. 2:11 [13]). Milgrom explains this as the result of an $\mathrm{H}$ redactor in Babylon (Jacob Milgrom, Leviticus 23-27 [AB 3B; New York: Doubleday, 2001], 1956). A simpler explanation, however, may be that the Shabbat is integral to the festival cycle in the dating of the festivals of Bikkurim and Shavuot (Lv. 23:11, 15-16; see J.E. Hartley, Leviticus [WBC; Dallas: Word, 1992]). At the same time, the Shabbat is not lunar-based and therefore distinct from the annual festival cycle. 


\section{Ancient Near Eastern Background}

מוֹעיד is probably derived from the root רועד of וערד is attested in Near Eastern languages other than Hebrew, including Akkadian (adannu), Arabic (maw'id), Ugaritic ( $m$ ' $d$ ) and Aramaic $\left.\left(m \bar{o}^{a} \underline{d} \underline{a}\right)^{\prime}\right)$. The rather consistent witness of Akkadian lexicographers is that Akkadian attests to the 'appointed time' or 'period of time' rendering of מוֹעיד in the Hebrew Bible.25 The same is true with Arabic. ${ }^{26}$ In Ugaritic, of the five occurrences of $m^{\prime} d$, all refer to $p h r m$ ' $d$, a place/time of assembly [of the gods], an expression that

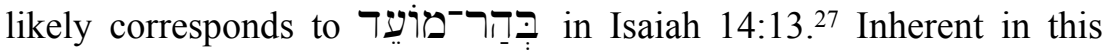
expression may be an allusion to corresponding festivals on earth. ${ }^{28}$ Finally, the one occurrence we have of the Aramaic $m \bar{o}^{-a} \underline{d} \bar{a}^{\prime}$ refers to a

24 'The triliteral root עועד is evidently another expansion of the biliteral עד root. Although it is listed in Hebrew lexicons under עי 'עד the Niphal, Hiphil, and Hophal forms of the verb indicate that the first radical is 1 . This is confirmed by the cognates. The idea of "fixing a time" is represented by this root in all Semitic languages. Not infrequently derivatives of the root have reference to fixed religious seasons which recur at regular intervals so that the fundamental notion of "recurrence" appears here also. Many of the derivatives of וער, however, take on the extended meanings of "appoint" in a more general sense, "assemble at appointed times or places", and "agree upon" some appointed or accepted terms, that is, "promise", "predict" or "threaten"...Derivatives of the roots עוד and ועד appear a good deal in covenant contexts in the Old Testament. They occur particularly frequently in reference to the covenant between Yahweh and Israel' (J.A. Thompson, 'Expansions of the ער Root', Journal of Semitic Studies 10 [1965] 229, 239).

25 Ignace J. Gelb, Benno Landsberger, A. Leo Oppenheim and Erica Reiner (eds.), The Assyrian Dictionary of the Oriental Institute of the University of Chicago I (Chicago: Oriental Institute, 1964), 97; Bruno Meissner \& Wolfram von Soden, Akkadisches Handwörterbuch I (Wiesbaden: Harrassowitz, 1965), 10; Jeremy Black, Andrew George \& Nicholas Postgate (eds.), A Concise Dictionary of Akkadian (SANTAG 5; Wiesbaden: Harrassowitz, 2000), 4; John Huehnergard, A Grammar of Akkadian (HSMS 45; Winona Lake: Eisenbrauns, 2000), 486.

26 Cyrus H. Gordon, Ugaritic Textbook (Analecta Orientalia 38; Roma: Pontificio Istituto Biblico, 1998), 19:1512; Edward William Lane, An Arabic-English Lexicon I (Part 8; ed. Stanley Lane-Poole; London: Williams \& Norgate, 1893), 2952-953. See George Percy Badger, An English-Arabic Lexicon (London: C. Kegan Paul, 1881), 1102; John Penrice, A Dictionary and Glossary of the Koran (London: Curzon, 1971), 160.

27 Richard E. Whitaker, A Concordance of the Ugaritic Literature (Cambridge, MA: Harvard University Press, 1972), 428. See Gordon, 137:14, 31, 16-17; 435 (19:1512).

28 ' $\ldots$. both the Ugaritic and OT contexts suggest rather a "fixed time for the assembly (of the gods)"; in neither instance is the reference to ad hoc meetings, but rather to regularly recurring occasions which presumably are to be celebrated concurrently as festivals on earth as well' (Koch, 'מוער', 171). See H. Donner \& W. Röllig, A Synoptic Concordance of Aramaic Inscriptions (eds. Walter E. Aufrecht, J. Arthur Baird \& David Noel Freedman; Missoula, MT: Scholars, 1975). 
'festival'. ${ }^{29}$ This data indicates that cognate equivalents of מוֹעֵ ANE literature tend to correlate with the semantic range of מוֹער in the Hebrew Bible. 'Appointed time' is the most common meaning, but 'festival' and 'period of time' are also attested.

Two ANE creation accounts (Egyptian and Mesopotamian) exist in which festivals are attested. In an Egyptian creation account redacted during the time of the Ramessides, ${ }^{30}$ the sun god Re declares that he brought into being 'hours', 'days' and 'New year festivals', language similar to Genesis 1:14. ${ }^{31}$ The Mesopotamian Enūma Eliš creation story also refers to 'New Year's [day]' (ina zag-[muk-ki]) in Tablet V [40-42]) following the installation of moon and sun. ${ }^{32}$ That 'New Year's [day]' here was understood to mean a festal observance is supported by the reading of the Enūma Eliš on the fourth day of the New Year festival in Babylon. ${ }^{33}$ Moreover, in the Mesopotamian world

29 Charles-F. Jean \& JacobHoftijzer, Dictionnaire des Inscriptions Sémitiques de L'Ouest (Leiden: Brill, 1965), 145. See Phrahang-I-Pahlavik cited in E. Ebeling, Das aramäisch-mittelpersische Glossar Frahang-I-Pahlavik im Lichte der assyriologischen Forschung (Mitteilungen der altorientalischen Gesellschaft xiv/I; Leipzig: Harrassowitz, 1941), xix 8.

30 Numerous parallels exist between Hebrew and Egyptian creation accounts, the study of which has been somewhat neglected in modern scholarship due to the focus on Mesopotamian accounts. See John D. Currid, 'An Examination of the Egyptian Background of the Genesis Cosmogony', Biblische Zeitschrift 35 (1991) 19, 29. For a survey of Egyptian creation accounts, see J.P. Allen, Genesis in Egypt: The Philosophy of Ancient Egyptian Creation Accounts (New Haven: Yale Egyptological Studies, 1988). Most significant of the parallels is that the Egyptians believed in one creator god who made the universe ex nihilo by verbal fiat. Cf. Currid, 'An Examination', 2021; R.T. Rundle Clark, Myth and Symbol in Ancient Egypt (London: Thames and Hudson, 1959), 44.

31 Hellmut Brunner (tr.), 'Egyptian Texts: Re describes his creation', in Near Eastern Religious Texts relating to the Old Testament (ed. Walter Beyerlin; London: SCM, 1978), 5-6. This text is published in A.H. Gardiner, Hieratic Papyri in the British Museum, 3rd Series (1935), plates 64-65.

32 B. Landsberger \& J.V. Kinnier Wilson, 'The Fifth Tablet of Enuma Eliš', JNES 20 (1961) 157-61. For other translations, see E.A. Speiser , 'Akkadian Myths and Epics', in James B. Pritchard (ed.), Ancient Near Eastern Texts Relating to the Old Testament (Princeton: Princeton University Press, 1950), 67-68; A.K. Grayson, 'Akkadian Myths and Epics: The Creation Epic, Additions to Table V', in Pritchard (ed.), The Ancient Near East II (Princeton: Princeton University Press, 1975), 1.

33 Pritchard, Ancient Near Eastern Texts, 60, 332; Mark E. Cohen, The Cultic Calendars of the Ancient Near East (Bethesda: CDL, 1993), 444. I would conjecture that the climax of the New Year reading of Enüma Eliš was the Table V narrative concerning the inception of 'New Year's [day]' following the installation of moon and sun. Here the day of worship is explicitly mentioned and its origin is highlighted in the liturgy, bringing to mind the themes of luminaries (stars, moon, sun $[2,4,6,12,15,19$, $27,45])$, time (night and day, days, weeks, months, years $[2-5,13-18,22,46])$ and 
from the time of the third millennium B.C.E., the New Year was typically a spring cultic festival and the first celebration of an annual cycle of festivals divided into two axes. ${ }^{34}$ Much attention was given to its ritual observance. ${ }^{35}$

\section{Second Temple Jewish Literature}

The Second Temple period is important for assessing how מוֹעִדים in Genesis 1:14 was read by diverse streams within early Judaism.

\section{a) Septuagint}

מוֹעִדים The Septuagint translators chose the word kaıpoús to render in Genesis 1:14. There are no variants. ${ }^{36}$ The plural noun appears in eight other Septuagint Pentateuch passages, always in reference to festival times. The three annual pilgrimage festivals of Pesach/Matzot, Shavuot, and Sukkot are particularly in view (Ex. 13:10; 23:14, 17; 34:23, 24; Nu. 9:3; Dt. 16:16). For this reason, Wevers suggests in Notes on the Greek Text of Genesis that the '... word кalpov's probably does not mean "seasons of the year" but rather the designated times, i.e. the festivals, the "מוֹשִِדים

\section{b) Wisdom of Ben Sira 43:2-8}

In the Wisdom of Ben Sira 43:2-8, the writer alludes to the creation account. The sun is described as the 'work of the Most High ... Great is the Lord who made it ...'. Similarly, the moon is described as 'governing the times', 'a sign', 'shining in the vault of the heavens', all

appointed festivals (41), all of which find parallels in the fourth day of the Genesis creation account.

34 Cohen, Cultic Calendars, 14-20; Norman H. Snaith, 'New Year Festivals in Mesopotamia and Syria', in The Jewish New Year Festival: Its Origins and Development (London: SPCK, 1947), 204-220; Daniel E. Fleming, Time at Emar: The Cultic Calendar and the Rituals from the Diviner's Archive (Winona Lake: Eisenbrauns, 2000), 126-33.

35 Walter Beyerlin, 'Mesopotamian Texts', in Near Eastern Religious Texts relating to the Old Testament (ed. Walter Beyerlin; London: SCM, 1978), 81.

36 John William Wevers (ed.), Septuaginta Vetus Testamentum Graecum Auctoritate Academiae Scientiarum Gottingensis editum I (Göttingen: Vandenhoeck \& Ruprecht, 1974), 78. See also Alan E. Brooke \& Norman McLean (eds.), The Old Testament in Greek I (London: CUP, 1906), 2.

37 John William Wevers, Notes on the Greek Text of Genesis (SBL Septuagint and Cognate Studies Series 35; Atlanta: Scholars, 1993), 8. 
allusions to Genesis 1. In this context, and most relevant to this study, the writer declares, 'From the moon comes the sign for festal days'.

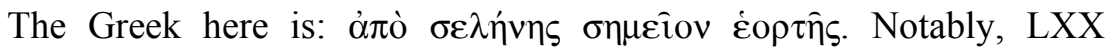

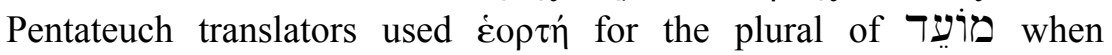
referring to festivals (Lv. 23:2 [2×], 4, 37, 44; Nu. 10:10; 15:3; 29:39). מוֹעיד Moreover, Hebrew fragments discovered at Masada confirm that was included in the Hebrew MS of Ben Sira 43:6-7 along with the word for pilgrimage festival (2ח). ${ }^{38}$ The combination of these two words for Israelite feast day celebrations is found throughout the Hebrew Bible (e.g. Ex. 23:15; 34:18; Lv. 23:4-6; Ho. 9:5).

\section{c) Jubilees 2:8-10}

The Book of Jubilees 2:8-10 includes the following midrashic interpretation of Genesis 1:14-19:

And on the fourth day he made the sun and the moon and the stars. And he set them in the firmament of heaven so that they might give light upon the whole earth and rule over the day and the night and separate light and darkness. And the LORD set the sun as a great sign upon the earth for days, sabbaths, months, feast (days), years, sabbaths of years, jubilees, and for all of the (appointed) times of the years - and it separates the light from the darkness - and so that everything which sprouts and grows upon the earth might surely prosper. These three kinds he made on the fourth day (Jub 2:8-10). ${ }^{39}$

It is clear from the midrash ("And the LORD set the $\operatorname{sun}^{40}$ as a great sign upon the earth for days, sabbaths, months, feast [days], years, sabbaths of years, jubilees, and for all of the [appointed] times of the years') that the author interprets מוֹשֶרִים in Genesis 1:14 to be a reference to Israel's calendar. ${ }^{41}$

38 Yigael Yadin, The Ben Sira Scroll from Masada: With Introduction, Emendations and Commentary (Jerusalem: Israel Exploration Society and the Shrine of the Book, 1965), 28-29.

39 O.S. Wintermute (tr.), 'Jubilees', in The Old Testament Pseudepigrapha II (ed. James H. Charlesworth; Garden City: Doubleday, 1985), 56. VanderKam's translation of verse 9 differs only slightly, 'The Lord appointed the sun as a great sign above the earth for days, sabbaths, months, festivals, years, sabbaths of years, jubilees, and all times of he years' (VanderKam, Calendars, 28).

40 The writer regards the sun as the primary luminary that regulates Israel's calendar. This is consistent with the 364-day solar calendar that is described in the Book of Jubilees.

41 4Q216 VI (4Qjub 2:7-12) was unfortunately in very poor condition. Martinez reconstructs vv. 7-8: '[light and darkness. And he placed the sun as a gr]eat [sign above the earth] for the day[s], the [sa]bbaths, the [months], [the feasts, the years, the weeks of years and the jubi]lees and for all the cyc[les of the years.]' (Florentino García Martínez \& Eibert J.C. Tigchelaar, The Dead Sea Scrolls Study Edition I 


\section{d) Dead Sea Scrolls}

The inclusion of ולמועדים in 4QGen ${ }^{\mathrm{b}}, 4 \mathrm{QGen}^{\mathrm{g}}$ and $4 \mathrm{QGen}^{\mathrm{k}}$ is confirmatory of the MT orthography. ${ }^{42}$ The only omission found is in 4QGen ${ }^{g}$ and 4QGen ${ }^{\mathrm{k}}$ (ולמעדים) where the mater lectionis 7 is not there.

Clines lists 258 occurrences of מוֹעיר in the Dead Sea Scrolls apart from 4QGen. Occurrences are broken down into the following semantic categories: Appointed time, due season (141); festival, (time of) appointed feast (92); agreement, appointment (18); meeting, assembly (4); and Tent of Meeting (3). ${ }^{43}$

The Qumran community followed the Jubilees calendar, which consisted of a fifty-two week year, each quarter consisting of thirteen weeks (Jub. 6:29-30) with some form of intercalation. ${ }^{44}$ Barthélemy has argued that the Qumran New Year annually occurred on Wednesday, the fourth day of the week, and suggests that this was to commemorate the fourth day of creation when the luminaries were installed. ${ }^{45}$ Jaubert's critical study of the Jubilees calendar confirms Barthélemy's theory. Jaubert demonstrates that, when one follows the Jubilees calendar, the festivals annually fall on the same days of the week: Wednesday, Friday and Sunday. Wednesday appears to be the most prominent of these days since each trimester of the Jubilees calendar begins on a Wednesday and almost all of the appointed

(Grand Rapids: Eerdmans, 1997), 463. Given the Genesis 1:14 context, I conjecture that the original included מוֹעַדרים for 'feasts'.

42 Eugene Ulrich, Frank Moore Cross, James R. Davila, et al (eds.), Discoveries in the Judaean Desert XII: Qumran Cave 4 VII Genesis to Numbers (Oxford: Clarendon, 1994), 33, 59, 77. See plates VI-VIII (4QGen ${ }^{\mathrm{b}}$ ) and XII (4QGen $\left.{ }^{\mathrm{g}}, 4 \mathrm{QGen}{ }^{\mathrm{k}}\right)$.

43 David J.A. Clines (ed.), The Dictionary of Classical Hebrew V (Sheffield: Sheffield Academic, 2001), 179-82. See also Gershon Brin, The Concept of Time in the Bible and the Dead Sea Scrolls (Leiden: Brill, 2001), 253-63.

44 VanderKam, Calendars, 111.

45 In support of this thesis, Barthélemy quotes the Moslem writer Al-Biruni (c. 9731048), 'Abu-Isa Alwarrak speaks in his Kitab al-Makalat of a Jewish sect known as the Maghariba, who claim that festivals are legal only when the moon appears full in Palestine in the night of Wednesday which follows the day of Tuesday, after sun-set. This is their New Year's Day. It is from this day that the days and months are reckoned and that the annual cycle of festivals begins. For God created the two great givers of light on a Wednesday. Likewise, they do not allow that the Pasch [=Passover] fall on any day other than Wednesday'. See D. Barthélemy, 'Notes en marge de publication récentes sur les manuscrits de Qumran', Revue Biblique 59 (1952) 199-203. Quoted in VanderKam, Calendars, 53. See also E. Sachau, The Chronology of Ancient Nations (London, 1879), 278. 
festivals fall on a Wednesday, most notably the pilgrimage festivals. ${ }^{46}$ The existence of a link between these Wednesday (fourth day) festival celebrations and מוֹעִדִים in the fourth day of creation has been suggested by VanderKam, ${ }^{47}$ Wenham, ${ }^{48}$ Beauchamp, ${ }^{49}$ and Vogels. ${ }^{50}$

\section{e) Philo}

Philo wrote extensively on Israel's festivals and refers to the divine purpose of the luminaries (Gn. 1:14) in De Opificio Mundi: ${ }^{51}$

One purpose was to give light; another to be signs; a third duly to fix seasons

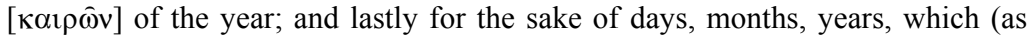
we all know) have served as measures of time and given birth to number (Philo, Opif. 18.55 [Colson and Whitaker LCL]). ${ }^{52}$

That Philo equates katpoús with the four seasons of the year is confirmed by his elucidation of Genesis 1:14 a few paragraphs later:

It is added, moreover, 'and for appointed times' [кaıрov̀c] (Gen. i.14). By 'appointed times' [Kalpoìs] Moses understood the four seasons of the year ... (Philo, Opif. 19.59 [Colson and Whitaker LCL]).

Philo uses Kaıpoús in its broadest sense ('appointed times') to tease out the 'four seasons' rendering. He does not address the common use of the plural noun elsewhere in the Greek Pentateuch to designate Israel's cultic/harvest festivals.

Notably, Philo's case for a 'four seasons' rendering is based mainly on allegorical interpretation. In the middle of a lengthy discussion on the hidden meaning of the fourth digit, Philo suggests that the word Kalpov́s in Genesis 1:14 must relate to the four seasons since it first appears in the context of the fourth day of creation. ${ }^{53}$ Philo's emphasis on numbers (in particular $4,7,6,10$ ) to unlock the meaning of a biblical text was a reflection of his Hellenistic approach to interpreting

46 A. Jaubert, The Date of the Last Supper (tr. I. Rafferty; Staten Island: Alba, 1965), 52. See VanderKam, Calendars, 54-57. The fourth day festivals included: Pesach/Matzot, Shavuot, Sukkot, Purim, Bikkurim and Yom Teruah.

47 VanderKam, Calendars, 55-56

48 Gordon J. Wenham, The Book of Leviticus (NICOT; Grand Rapids: Eerdmans, 1979), 302 n. 4.

49 Beauchamp, Création et séparation, 113-16.

50 Vogels, 'Cultic and Civil Calendars', 177.

51 For a survey of Philo's views on the Jewish calendar, see Samuel Belkin, Philo and the Oral Law: The Philonic Interpretation of Biblical Law in Relation to the Palestinian Halakah (Cambridge, MA: Harvard University Press, 1940), 192-218.

52 Cf. Philo, Aet. 4.19; Opif. 14.45.

53 Philo, Opif. 16.52; Plant. 28.120. 
the Hebrew Bible. In De Opificio Mundi, he draws heavily from the Pythagoreans. ${ }^{54}$

\section{Conclusion}

Confirming the trend in biblical scholarship, we conclude that a reasonable case can be made for rendering מוֹעִ מוֹדים in Genesis 1:14 as 'festivals' or 'festivals and seasons'. The plural form of מוֹעים means 'festivals' one hundred percent of the time in the Torah. Moreover, and most important for this study, the exact lexical form of מוֹעיד in Genesis 1:14 (m.pl. w/ל prep.) means 'festivals' one hundred percent of the time in the Hebrew Bible; one instance (Ps. 104:19) refers directly to Genesis 1:14. Literary context and ANE background bolster the '[cultic] festivals' reading. Genesis $1: 1-2: 3$ is replete with priestly/liturgical language and havdil imagery. Among ANE creation accounts similar to Genesis 1, an Egyptian and Mesopotamian one (the Enūma Elǐs) were found which make reference to New Year festivals. Finally, Second Temple Jewish literature generally upholds the 'festivals' translation. Philo, an exception, favours the 'four seasons' interpretation based on allegorical/Pythagorean premises. Looking back over the evidence, the weight of biblical exegesis and earlier sources seems to support the 'festivals' or 'festivals and seasons' reading. Later sources, such as Philo, expectedly give rise to a diversity of new interpretations.

54 F.H. Colson and G.H. Whitaker, 'On the Account of the World's Creation Given by Moses (De Opificio Mundi): Introduction', in Philo, Book I (LCL; Cambridge: Harvard University Press, c1929), xvii. 